\title{
Nasal septal pediculate carcinoma in situ: differential diagnosis
}

\author{
Faculdade de Medicina de Jundiaí - São Paulo, Brazil
}

\begin{abstract}
Pediculated lesions of the nasal cavities are relatively common in daily practice, and include inflammatory polyps, benign tumors (papillomas being the most common), malignant tumors, and specific processes, such as polypoid rhinosporidiosis. The authors describe a female patient with a warty, pediculated, and asymptomatic lesion in the nasal septal mucosa. The anatomo-pathological exam showed this to be a "carcinoma in situ." The few bibliographic citations report only an association between the tumor and contact with wood dust, such as oak, ebony and beech. The patient was not exposed to these elements. It is important to emphasize the routine performance of a complete otolaryngological exam for patients seeking out specialists, in order to detect potentially malignant lesions whose early removal would permit a complete cure.
\end{abstract}

UNITERMS: Nose. Carcinoma in situ.

\section{INTRODUCTION}

$\mathrm{P}$ ediculated lesions of the nasal cavities are common in clinical otolaryngological practice. They may appear in nasal cavities and paranasal sinuses, and cause symptoms such as nasal obstruction, rhinorrea, epistaxis, or no symptoms at all. Unfortunately, the malignant lesions can grow undetected and be diagnosed too late, worsening the prognosis.

We report a rare case of malignant transformation, from a benign nasal septal papilloma to an carcinoma "in situ." There are no existing scientific reports on this topic, although there are many reports of

\section{Adress for correspondence:}

Edmir Américo Lourenço

Rua do Retiro, $n^{\circ} 424 / 5^{\circ}$ andar, conj. 53/54 - Anhangabaú Jundiai/SP - Brasil - CEP 13209-000 adenocarcinomas "in situ." The principal diagnostic differentials are emphazied here.

\section{CASE REPORT}

A 45-year old housewife, with otological complaints and no prior history of any significant illnesses, was examined at our office. A complete otolaryngological exam was normal. Some months later, during a routine exam, an anterior rhinoscopy with a nasal speculum revealed a pediculated lesion in the nasal septal mucosa, about $6 \mathrm{ml}$ in diameter, gray in color, wart-like appearance, and no ulceration. This lesion was totally asymptomatic, with no bleeding or pain.

This inner nose lesion was submitted to total surgical extirpation under topical anesthesia, and the pathologist's exam showed it to be a carcinoma "in situ." 


\section{HISTOLOGICAL FINDINGS}

Histological slices of the block showed a polypoid lesion of the nasal septal mucosa. The stratified, pavimentous epithelium was thick, and highly cellular with a lack of maturation, characterizing severe dysplasia, and, therefore, a carcinoma "in situ." Throughout the thickness of the ephitelium we could see cells with highly-colored nuclei, few and irregular mitotic figures, characterizing cellular restlessness, or rather, cytologic atypia. The basal membrane was intact, and in the stroma we could see a mild chronic linfoplasmocitary inflammatory infiltrate and vascular proliferation. This was a true papilloma, with atypias, and consequently, a precancerous lesion.

\section{DISCUSSION}

The basal membrane separates the nasal epithelium from the corium, and this membrane is formed by the association of basal lamina (produced by epithelial cells), glycoproteins, reticular fibers and proteins. The basal membrane is the most important landmark in the classification of epithelium tumors. A tumor is classified as "in situ" when the neoplastic cells do not go beyond this membrane. If there is no corium invasion, the prognosis is generally good (if the lesion is completely extirpated).'

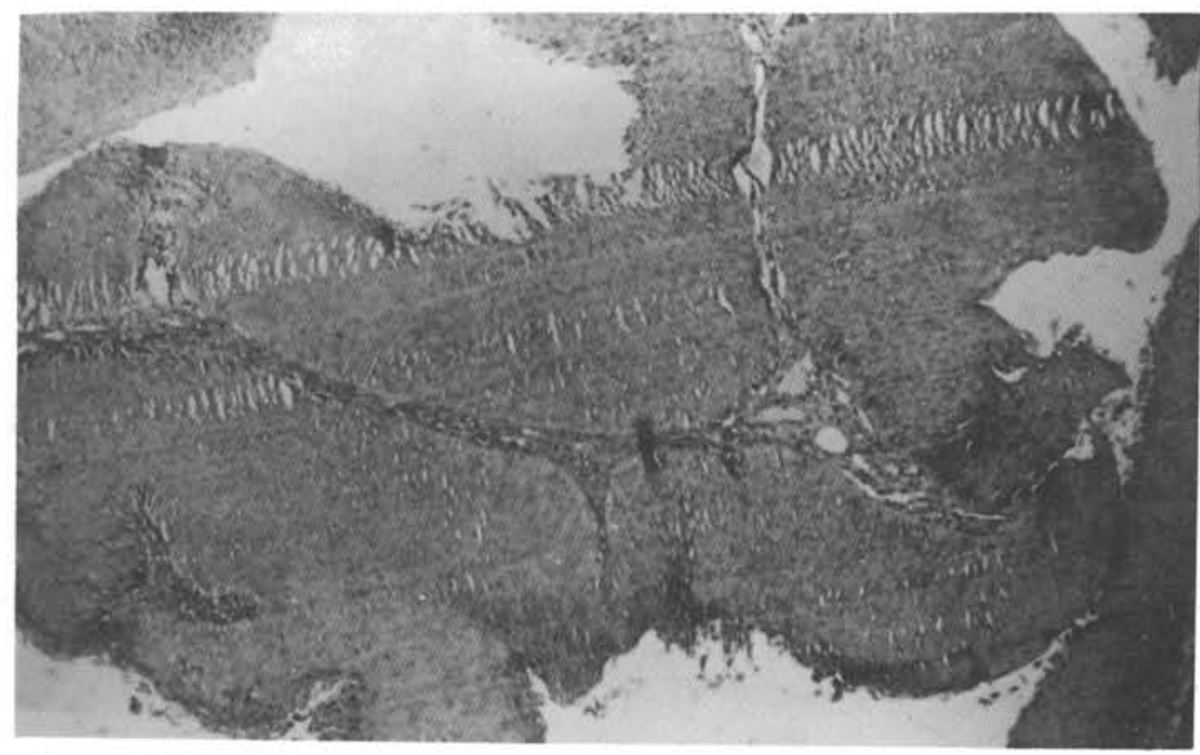

Figure 1 - Polypoid lesion with thick, stratified pavimentous epithelium ( $x 40 ; \mathrm{H} \& E$ ).
In the differential diagnosis of nasal cavity pediculated lesions, we can cite the inflammatory polyps, tumoral lesions (benign and malignant), and the specific pathologies.

Inflammatory polyps can originate from an allergic and/or infectious process. They can appear as smooth, intranasal pediculated masses, edematous, with a pale or hyperemic surface. Histologically, there is a variable inflammatory infiltrate and hyperplasia in the conjunctive tissue. Generally located in the medium meatus, and frequently coexisting with chronic sinus problems, they often present symptoms like obstruction, itching, sneezing and rhinorrea.

Among benign tumors, papillomas are the most common. They have a wart-like form, and bleed easily. They are less frequent than the inflammatory polyps, occurring more commonly in males, and unilaterally. Histologically, they have an epithelial nature, and can degenerate and later become malignant. The isolated plasmocitoma can originated from lymphoid tissue. The neoplastic epithelial cells are usually squamous, but may be cuboidal, colunmnar, or ciliated. Proliferation of basal cells is usually present, and microscopic mucous cysts are frequent in the interior of the epithelium.

The supporting corium is edematous, and it contains varying amounts of chronic inflammatory cells, including eosinophils. Most papillomas are exophytic, with a central core of connective tissue and are usually located on the nasal septum. Those that on the lateral walls are more frequently inverted papillomas, characterized by a downward proliferation of the epithelium into the underlying corium; a pattern which may easily be confused with well-differentiated squamous carcinoma. Rarely do squamous carcinomas (about $1-3$ percent) arise from recurrent nasal papillomas. $^{2}$

The nasal vestibulum keratotic papilloma is a benign lesion which arises on the vestibular skin surface, or at the mucocutaneous junction of the septum, and supposedly results from repeated trauma. It is a warty growth, characterized microscopically by hyperkeratosis, papillomatosis and acanthosis. ${ }^{4}$

Among the specific diseases, the most common is rhinosporidiosis. It manifests as a polypoid 
form, and its diagnosis is confirmed by the histological finding of the ethiological agent, Rhinosporidium seeberi.

Benign and malignant glandular neoplasms are quite uncommon in the nasal cavity and paranasal sinuses. The adenocarcinomas account for only 4-8 percent of nasal and paranasal sinus carcinomas. They are found more frequently in males, and in the fifth decade of life. These tumors can originate from the surface of the respiratory epithelium, or from glands located in the epithelium. We found many reports of nasal septal pleomorficadenoma, sometimes maquerading as a carcinoma. ${ }^{3.4}$

The expression adenocarcinoma "in situ" is controversial. Pathologists have given preference to the term "precocious adenocarcinoma." They are composed of glands coated with atypical cells, within the corium, with no infiltration of the basal membrane.

The mucinous adenocarcinoma may be papillary or solid. Most of the papillary tumors are moderately or well-differentiated, and some of them contain cystic structures. Histologically, these tumors often resemble colonic carcinomas. They are locally aggressive, but seldom metastasize, although many patients die from local extension or dissemination of the tumor. There is a higher proportion of wood workers exposed to beech, oak, and ebony dust among patients with adenocarcinoma of the nose and paranasal sinuses, than in the general population. It has been discussed that the carcinogenic effect is due to the mixed exposure to both wood dust and other chemicals used in woodworking, such as: preservatives; varnishes; solvents; and others agents like formaldehyde, chromium, thorotrast, isoprophyl alcohol, nickel, smoke, and ethyl-alcohol. These agents

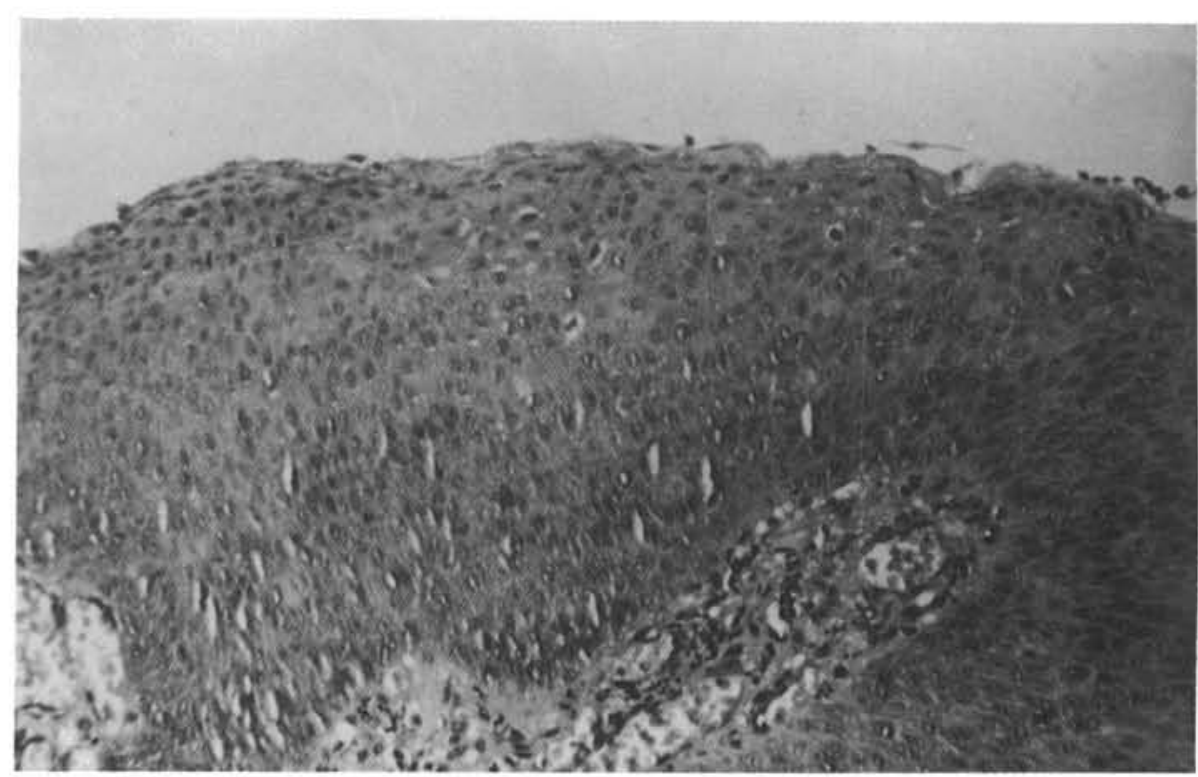

Figure 2 - Thick, stratified pavimentous epithelium, highly cellular, and with colored nuclei and $a$ few and irregular mitotic figures, characteristics of a lack of maturation ( $x 100 ; H \& E)$.

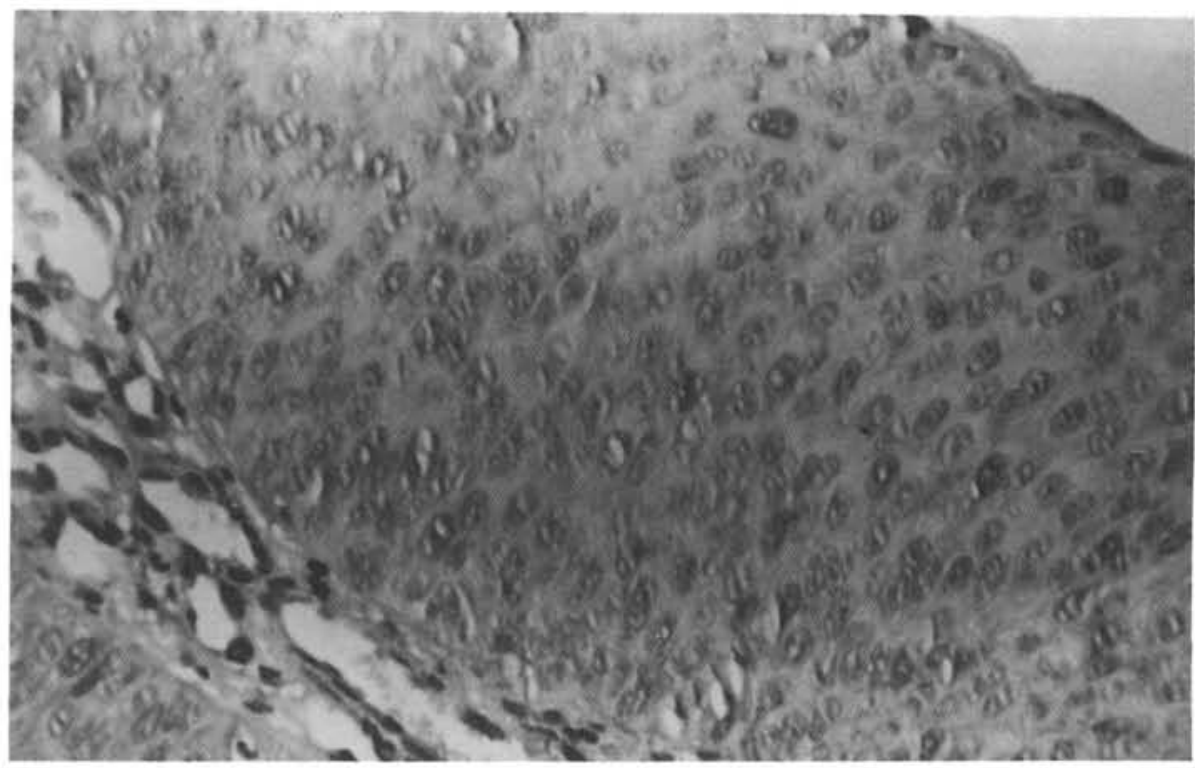

Figure 3 -Intact basal membrane and corium showing a mild chronic linfoplasmocitary inflammatory infiltrate and vascular proliferation ( $\mathrm{x} 400 ; \mathrm{H} \& \mathrm{E})$.

increase the incidence of nasosinusal carcinomas by 500 times. ${ }^{3.4}$ Our patient had not been exposed to any of these elements.

It is important to emphasize that otolaryngological exams must be thorough and accurate for all patients consulting specialists, especially for the early detection of potentially malignant lesions, whose early removal can lead to a complete cure. 


\section{RESUMO}

Lesōes pediculadas das cavidades nasais são relativamente comuns na prática otorrinolaringológica diária, entre elas os pólipos inflamatórios, os tumores benignos, tumores malignos e processos especificos, como a rinosporidiose. Os autores descrevem uma paciente, do lar, portadora de uma lesão verrucosa e pediculada assintomática na mucosa do septo nasal. 0 exame anátomo-patológico mostrou tratar-se de um "carcinoma in situ". As citaçōes bibliográficas são pouco numerosas e somente reportam concomitância entre adenocarcinomas in situ e o contato com pó de madeira (faia, ébano e carvalho). É importante enfatizar a importância da realizaçăo do exame otorrinolaringológico completo, rotineiramente, em todos os pacientes que procuram o especialista, especificamente na detecçāo de lesōes potencialmente malignas, cuja remoção precoce permite cura completa.

\section{REFERENCES}

1. Achenson ED, Hadfield EH, MacBeth RG. Carcinoma of the nasal cavity and acessory sinuses in woodworkers. Lancet 1967; I:311-2.

2. Junqueira LC, Carneiro J. In: Histologia Básica, 6th Ed., Rio de Janeiro: Guanabara, 1985:343-8.
3. Kleinsasser O, Schoroeder HG, Mayer-Brix, J. Preinvasive stages of adenocarcinoma of the nose after exposure to wood dust. Eur Arch Otorhinolaryngol 1991;248(4):222-9.

4. Liao BS, Hilsinger Jr. RL, Chong E. Septal pleomorphic adenoma masquerading as squamous cell carcinoma. ENT Journal 1993;72(12):781-2. 